Provided by the author(s) and University of Galway in accordance with publisher policies. Please cite the published version when available.

\begin{tabular}{|c|c|}
\hline Title & $\begin{array}{l}\text { Revisiting the reservations dialogue: negotiating diversity } \\
\text { while preserving universality through human rights law }\end{array}$ \\
\hline Author(s) & Yahyaoui Krivenko, Ekaterina \\
\hline $\begin{array}{c}\text { Publication } \\
\text { Date }\end{array}$ & 2016-04-30 \\
\hline $\begin{array}{l}\text { Publication } \\
\text { Information }\end{array}$ & $\begin{array}{l}\text { Yahyaoui Krivenko E (2016) 'Revisiting the Reservations } \\
\text { Dialogue: Negotiating Diversity while Preserving Universality } \\
\text { Through Human Rights Law' In: Machiko Kanetake and } \\
\text { André Nollkaemper (eds.), The Rule of Law at the National } \\
\text { and International Levels: Contestations and Deference. Oxford } \\
\text { : Hart. }\end{array}$ \\
\hline Publisher & Hart Publishing \\
\hline $\begin{array}{l}\text { Link to } \\
\text { publisher's } \\
\text { version }\end{array}$ & $\begin{array}{l}\text { http://www.hartpub.co.uk/BookDetails.aspx?ISBN=978184946 } \\
6677\end{array}$ \\
\hline Item record & http://hdl.handle.net/10379/5761 \\
\hline
\end{tabular}

Downloaded 2023-04-26T07:16:47Z

Some rights reserved. For more information, please see the item record link above.

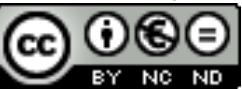




\title{
Revisiting the Reservations Dialogue: Negotiating Diversity while Preserving Universality through Human Rights Law
}

\author{
Ekaterina Yahyaoui Krivenko*
}

I Introduction

The rule of law and human rights are two notions widely accepted as having positive values in both national and international law. However, the understanding of the contents and meaning of these two notions, including their relationship, is still a work in progress within international law scholarship. The diversity of states' legal cultures, societal structures, and social practices makes it challenging to gain a better understanding about, and a more precise definition of, both the rule of law and human rights. The difficulty in understanding the relationships between the two concepts arises 
precisely because human rights often encounter two ostensibly contrasting demands of universality and diversity. To meet these two demands may appear to undermine the elements of the rule of law, such as certainty and foreseeability. This chapter addresses this conceptual difficulty by proposing a new perspective with which to examine human rights and the rule of law. The chapter develops the perspective through the specific analysis on the reservations to human rights treaties. I choose to examine the reservations to human rights treaties as the cornerstone of the analysis because what can be observed within the context of states' reservations practice illuminates our understanding about the above described difficulty. Similarly, the reservations' practice illustrates the interactive processes through which universality and diversity are negotiated, and further provides us with the new understanding about the rule of law in human rights practices.

This chapter aims at furthering our understanding of the rule of law in the context of international human rights law. More specifically, it examines the question of how the value of relative uniformity and certainty, which may be seen as intrinsic in the rule of law, is balanced with the value of diversity while maintaining the universality of human rights. ${ }^{1}$ In answering these questions, I propose a specific concept of the rule of law at the 'international' level, in a way which is not built upon a parallel notion at the domestic level. By so doing, this chapter also contributes to enhancing our

\footnotetext{
*This chapter is based on the author's previous works, including: Yahyaoui Krivenko, 'The "Reservations Dialogue” as a Constitution-Making Process' (2013) 15 International Community Law Review 381.

${ }^{1}$ On the question of universality and diversity in human rights law, see also chs 10 (Legg), 13 (Donders and Vleugel) of this volume.
} 
understanding of the relationship between the rule of law in the national and international legal orders.

In order to address the above questions, the chapter analyses reservations to human rights treaties from the perspective of the dialogical understanding of the international rule of law. As will be demonstrated below, the issue of reservations highlights the tension between diversity and the universality of international human rights law. The reservation dialogue accommodates the tension, and, through this process, develops international human rights law and the international rule of law. Given that treaties are the major instruments to guarantee human rights, the very possibility of making reservations to human rights treaties, combined with the status attributed to human rights within the theories of the international rule of law, poses a question as to whether the rule of law can be reserved or 'opted out' of at the international level by a state's reservations.

I will address the relationship between the rule of law and international human rights law by using the notion of the 'reservations dialogue' developed initially by the International Law Commission's (ILC) Special Rapporteur on Reservations to Treaties, Alain Pellet. ${ }^{2}$ Building on his initial notion, I adopt a broader view and definition of the reservations dialogue. The broader view encompasses a fuller recognition of the role of various actors participating in the dialogue, multiple forms of the dialogue, and their

2 ILC, 'Seventeenth Report on Reservations to Treaties, by Alain Pellet, Special Rapporteur' UN Doc A/CN.4/647 (26 May 2011). See also Report of the International Law Commission, 'Guide to Practice on Reservations to Treaties, Adopted by the Commission at Its Sixty-Third Session' UN Doc A/66/10 (2011). The conclusions reached based on the reports of the Special Rapporteur are summarised in this report. 
effects. The broader view adopted in this chapter better allows us to reconcile human rights, on the one hand, which are among the core elements of the international rule of law (as will be described in section II below), and the regime of reservations, on the other hand, which permits states to limit and circumvent human rights and the international rule of law. In defining this broader vision of reservations dialogue and its functions within the international rule of law, I draw upon the actual practices of states and human rights treaty-monitoring bodies.

The broader vision of the reservations dialogue helps us understand its dynamics beyond the confines, not only of the Vienna Convention on the Law of Treaties, ${ }^{3}$ but also of the law of treaties in general, and allows us to take into consideration some nonlegal elements that play out in the dynamics of the reservations dialogue. I will argue that the adoption of the broader vision of the reservations dialogue matters because the view allows for a constructive and productive negotiation of inscription of the national diversity into the international rule of law. The broader vision of the reservations dialogue allows for more intensive input from domestic constituencies, and ultimately enhances the legitimacy of the international rule of law. I will also submit that the international rule of law cannot exist independently from these negotiative practices developing within the framework of the reservations regime. In fact, the very substance of today's international rule of law consists of these negotiative practices and their outcomes at any given point in time. These negotiative practices shall never stop; and

\footnotetext{
${ }^{3}$ Vienna Convention on the Law of Treaties, 23 May 1969, 1155 UNTS 311 (entered into force 27 Jan 1980) (1969).
} 
indeed, 'there is no place at which we could finally arrive'. ${ }^{4}$ However, as this chapter will demonstrate, this does not necessarily mean uncertainty and the absence of universality.

This chapter starts with a discussion of the notion of the rule of law especially as it has been interpreted in its application to law's regulation of international relations (section II). After a brief overview of the traditional vision of the reservations regime and the reservations dialogue, I will analyse the examples from state practice and demonstrate how the reservations regime and the reservations dialogue have been used by states for purposes beyond the traditional understanding of these notions (sections III-IV). Finally, I will provide the assessment of how these developments in state practice have impact on our understanding of the relationship between the domestic and international rule of law, and of some unique features of the 'international' rule of law. The chapter will also suggest how the reservations regime itself could be revised in order to become more conductive towards negotiative and dialogical practices, which are evaluated positively within the context of this chapter's reading of the rule of law.

\section{The Relationship between the Rule of Law Concept, Human Rights, and Universality}

\footnotetext{
${ }^{4}$ Katharine T Bartlett, 'Feminist Legal Methods' (1990) 103 Harvard Law Review 885.
} 
The relationships between the rule of law and human rights are controversial both in theory and practice. Rule of law has diverse meanings and interpretations depending on both time and space. Here, I attempt to present some existing dominant definitions of the concept of the rule of law, which are of particular importance to the arguments formulated in this chapter. Specific attention will be paid to the relationship between the rule of law and human rights. It is important to be aware of different connotations and meanings which we allude to when using the term 'rule of law'.

The general support for the rule of law is often motivated by the desire to place constraints on the arbitrary exercise of power and to prevent any arbitrary use of public power. From this point of view, the first important distinction we need to bear in mind is between the concept of the 'rule by law' and the concept of the 'rule of law'. 5 As one author noted in relation to the development of the rule of law in the early period, ' $[\mathrm{t}]$ hroughout this early period, ... law continued to be seen largely as a means by which to rule rather than a constraint on the rule as such' ${ }^{6}$

Summarising some generally accepted requirements of the rule of law, Jeremy Waldron enumerates the following:

\footnotetext{
5 See, eg, Simon Chesterman, 'An International Rule of Law?' (2008) 56 American Journal of Comparative Law 331, 333. According to the concept of the rule by law, a ruler agrees to exercise power in a non-arbitrary fashion, whereas the rule of law signifies that the ruler him/herself is bound by law (limited government). For the formal elements of the rule of law, see also ch 1 (Machiko Kanetake) of this volume.

${ }^{6}$ ibid 334.
} 
1. a requirement that people in positions of authority should exercise their power within a constraining framework of public norms...;

2. a requirement that there be general rules laid down clearly in advance...;

3. a requirement that there be court, which operate according to recognized standards of procedural due process or natural justice...;

4. a principle of legal equality ${ }^{7}$

Within this context it is important to understand the goals pursued by the rule of law by considering why exactly we value this notion, what we intend to achieve, and for whose benefit the rule of law is established. Arguably, one of the ultimate goals pursued by the rule of law is the protection of individual freedom. As one author observed regarding the rule of law's objectives, 'the whole point of the rule of law is to secure individual freedom by providing a predictable environment in which individuals can act freely, plan their affairs, and make their decisions'.

If this is one of the goals of the rule of law, on which the majority of, if not all, lawyers may agree, the above four components of the rule of law may appear too formalistic and procedural in nature. They seem to overlook the quality and nature of the 'law' component of the rule of law. For example, in a particular national setting, some of the aforementioned requirements (such as the principle of legal equality) can be readily met by very strict and intrusive laws which, at the same time, excessively limit

\footnotetext{
${ }^{7}$ Jeremy Waldron, 'Are Sovereigns Entitled to the Benefit of the International Rule of Law?' (2011) 22 European Journal of International Law 315, 316-17.

${ }^{8}$ Jeremy Waldron, 'The Rule of International Law' (2007) 30 Harvard Journal of Law and Public Policy $15,17$.
} 
the individual's freedom of action and decision-making. Individuals can still be discontented with those laws which apply to everyone equally, have a clear content, and are enforced by independent courts. Given that such laws frustrate one of the key objectives of the rule of law, at least certain substantive standards-such as 'constitutional rights' within domestic legal systems and 'human rights' at the international arena-should form an integral part of our understanding of the rule of law.

At the same time, the precise relationship between human rights and the rule of law remains unsettled. To some extent, human rights law has been discussed only as an instrument of guaranteeing, protecting, and promoting some rights associated with the traditional vision of the components of the rule of law, such as equality before the law or the right to a fair trial by independent and impartial tribunals. ${ }^{9}$

The UN's position on the rule of law is indeterminate about whether and to what extent human rights are intrinsic to it. This is illustrated by, for instance, the Declaration of the High-Level Meeting of the UN General Assembly on the Rule of Law at the National and International Levels adopted in $2012 .{ }^{10}$ The Declaration states that ' $[w] e$ reaffirm that human rights, the rule of law and democracy are interlinked and mutually reinforcing and that they belong to the universal and indivisible core values and principles of the United Nations' ${ }^{11}$ While this statement makes clear that human rights

\footnotetext{
${ }^{9}$ See, eg, Chesterman, 'An International Rule of Law?' (n 5) 344-45; Randall Peerenboom, 'Human Rights and Rule of Law: What's the Relationship?' (2005) 36 Georgetown Journal of International Law 809.

${ }^{10}$ UN GA Res adopted on 24 Sept 2012, 'Declaration of the High-level Meeting of the General Assembly on the Rule of Law at the National and International Levels' UN Doc A/RES/67/1 (30 Nov 2012).

${ }^{11}$ ibid para 5.
} 
and the rule of law cannot be separated, it continues to portray them as different and distinct notions. Also, while this statement puts the rule of law within a triad, the resolution devotes one separate paragraph to human rights, ${ }^{12}$ which may be a further indication that the rule of law and human rights are considered separately.

The unresolved question about the relationships between the rule of law and human rights also arises with regard to international human rights law. This is, for instance, illustrated by the UN Secretary-General's report that defined the rule of law in the following way:

[The rule of law] refers to a principle of governance in which all persons, institutions and entities, public and private, including the State itself, are accountable to laws that are publicly promulgated, equally enforced and independently adjudicated, and which are consistent with international human rights norms and standards. It requires, as well, measures to ensure adherence to the principles of supremacy of law, equality before the law, accountability to the law, fairness in the application of the law, separation of powers, participation in decision-making, legal certainty, avoidance of arbitrariness and procedural and legal transparency. ${ }^{13}$

The UN Secretary-General's definition seems to suggest an intrinsic link between international human rights and the rule of law. One could also interpret the

\footnotetext{
12 ibid para 6: 'We reaffirm the solemn commitment of our States to fulfil their obligations to promote universal respect for, and the observance and protection of, all human rights and fundamental freedoms'. Two other paragraphs are devoted to women's rights (ibid para 16) and children's rights (ibid para 17).

${ }^{13}$ Report of the Secretary-General, 'The Rule of Law and Transitional Justice in Conflict and PostConflict Societies' UN Doc S/2004/616 (23 Aug 2004) para 6 (emphasis added).
} 
above definition as finding a value-dictating quality in human rights placing them above the rule of law. While it is not entirely clear whether the definition given in this report applies to any rule of law or only to the domestic rule of law as promoted by the UN, it would, at any rate, be difficult to imagine an international rule of law without the requirement of consistency with human rights norms and standards, especially if the same is required from the domestic rule of law.

The relationship between international human rights and the rule of law is further complicated by the following statement in the preamble of the Universal Declaration of Human Rights: 'it is essential, if man is not to be compelled to have recourse, as a last resort, to rebellion against tyranny and oppression, that human rights should be protected by the rule of law'. ${ }^{14}$ If the aforementioned statement by the UN Secretary-General suggested that the rule of law needs human rights in order to function adequately, this statement reverses the assumption and affirms that human rights cannot exist and be guaranteed without the rule of law.

Thus, while these statements indicate that protection of individual rights and freedoms should form part of the substantive core of any rule of law, they do not provide any guidance to a range of relevant questions. For example, they contain no indication about the content and definition of these rights and values which should form the substantive core of the rule of law. Most importantly, if we leave the definition of this substantive core of the rule of law to each individual state, the actual implementation of international human rights in the domestic legal orders does not lend

\footnotetext{
14 'Universal Declaration of Human Rights', GA Res 217A (III) UN Doc A/810 (1948) 71, para 3 of the preamble.
} 
much support to the universality in international human rights law or ultimately the international rule of law.

The regime of reservations and the reservations dialogue provide an instructive insight into the relationships between the rule of law, international human rights law, universality, and diversity. Universality and equality are cornerstones of human rights protection as an ideal. The very idea behind the promotion and protection of human rights is that human beings should be equally protected in their dignity irrespective of their place of residence, their citizenship, etc. Yet universality is often a difficult issue for international human rights. Human rights treaties often allow for selective application, not only because states can choose to remain outside of the treaty regime, but also because states can tailor application of a particular treaty to their territory by entering reservations. Assuming that human rights form an integral part of the international rule of law, does the very possibility of making reservations mean that states can opt out of the international rule of law? Is an international rule of law at all possible under these conditions? We can observe here that the tension between universality and diversity so characteristic of the human rights law, but also of the reservations regime, ${ }^{15}$ starts haunting the rule of law too.

\footnotetext{
${ }^{15}$ Within the reservations regime, this tension is usually described as the necessity to strike a balance between the universality of participation and the integrity of a treaty: see, eg, Second Report on Reservations to Treaties UN Doc A/CN.4/477/Add 1, para 90, p 16. To some extent, we can see here a primary tension between two unifying and universalising tendencies which are regarded as not achievable simultaneously: one text for all states. However, this recognition of the impossibility to achieve these two goals simultaneously points out that in fact we need somehow to recognise and accept diversity. This becomes clearer in the following description of the balance between universality and integrity within the context of human rights treaties as a balance between 'the legitimate role of States to protect their
} 
As will be argued in the following sections of this chapter, universality and diversity are not exclusionary terms but inform each other. Following the deconstructionist and radical feminist critique of the binary thinking of the modern Western culture, ${ }^{16}$ the opposition between universality and diversity within the rule of law, human rights, and the reservations regime is reviewed and rethought. The central notion, which allows for a rethinking of these binary terms as oppositionary, is the reservations dialogue. In order to allow for a full development of the interconnectedness between these apparently opposed poles, the reservations dialogue is read and understood beyond the meaning attributed to it in the report of the Special Rapporteur and the Guide to Practice on Reservations to Treaties. ${ }^{17}$

As I noted above, human rights is intertwined with the rule of law at the international level; yet this does not mean that all the rule of law principles and

sovereign interests and the legitimate role of the treaty bodies to promote the effective guarantee of human rights' (Rosalyn Higgins, 'Introduction' in J P Gardner (ed), Human Rights as General Norms and a State's Rights to Opt Out: Reservations and Objections to Human Rights Conventions (London, British Institute of International and Comparative Law, 1997) xv.

16 See, eg, Hilary Charlesworth, Christine Chinkin, and Shelly Wright, 'Feminist Approaches to International Law' (1991) 85 American Journal of International Law 613.

${ }^{17}$ In the remainder of the chapter, I will refer on a few occasions to the narrow and insufficiently open approach of the Special Rapporteur. I would like to emphasise that I fully acknowledge the variety of constraints under which his work on the topic was performed. I also admit that most probably the final product of his 18 years of work (the Guide to Practice) was the best possible balance one could achieve under these constraints. However, now when the work is finished, there is a need to go further and use this work as creatively as possible. I hope that criticism expressed in this chapter will be regarded as a constructive engagement with and a tribute to the difficult work performed by the Special Rapporteur under a variety of constraints so vividly presented in Alain Pellet, 'The ILC Guide to Practice on Reservations to Treaties: A General Presentation by the Special Rapporteur' (2013) 24 European Journal of International Law 1061. 
requirements developed within the domestic legal system can be readily transposed to the level of international law and without affecting the function of such requirements. Despite the very strong affirmation of the UN General Assembly that 'the rule of law applies to all States equally, and to international organizations, including the United Nations and its principal organs, ${ }^{18}$ there are still numerous doubts and uncertainties surrounding the meaning of the rule of law at the international level.

The ambiguity of the international rule of law comes to the surface especially when we attempt to clarify how international and domestic legal systems interact, and what influence the domestic rule of law has on the international rule of law. This effort at clarification brings about a view of the international and the domestic rule of law as interrelated and interdependent concepts. The specific analysis conducted in this chapter on the functioning of the reservations regime and dialogue provides a very good tool for the clearer understanding of mechanisms and dynamics at play in developing the international rule of law.

\section{The Reservations Regime and the Reservations Dialogue}

\footnotetext{
${ }^{18}$ UN GA Res adopted on 24 Sept 2012 High-level Meeting Declaration on the Rule of Law (2012) (n 10) para 2.
} 
After having considered the meanings of the rule of law and its relationship to international human rights, the following section provides a brief introduction to the reservations regime before analysing the relevant examples from the practice developed by states within the context of the reservations dialogue.

\section{A Basics of the Reservations Regime}

When a state becomes a party to a treaty with a reservation, it is because the state is either unwilling or unable to respect all the obligations imposed on it by the treaty. In order to accommodate such states into the treaty, the current reservations regime ${ }^{19}$ allows them, when they become parties to a treaty, 'to exclude or to modify the legal effect of certain provisions of the treaty in their application to that State' ${ }^{20}$ Obviously, the state can become a party with the reservation only if at least one other state party to the treaty agrees to this modification or exclusion either expressly or tacitly. ${ }^{21}$ Moreover, states are not permitted to make reservations which would deprive the treaty of its

\footnotetext{
${ }^{19}$ For a more detailed general discussion of the reservations regime, see, eg, Frank Horn, Reservations and Interpretative Declarations to Multilateral Treaties (North-Holland, T.M.C. Asser Instituut, 1988); Alexander Behnsen, Das Vorbehaltsrecht völkerrechtlicher Verträge: Vorschlag einer Reform (Berlin, Duncker \& Humblot, 2007); Donald W Greig, 'Reservations: Equity as a Balancing Factor' (1995) 16 Australian Year Book of International Law 21; José Maria Ruda, 'Reservations to Treaties' (1975-III) 146 Recueil des Cours 11. For more recent literature, see Edward T Swaine, 'Reserving' (2006) 31 Yale Journal of International Law 307; Laurence R Helfer, 'Not Fully Committed? Reservations, Risk, and Treaty Design' (2006) 31 Yale Journal of International Law 367.

${ }^{20}$ Vienna Convention on the Law of Treaties (n 3) Art 2(1)(d).

${ }^{21}$ ibid Arts 20(4)(a), 20(4)(c), 20(5).
} 
object and purpose. ${ }^{22}$ States that do not agree with the modification or exclusion are given the chance to express their objections during a 12 -month period. ${ }^{23}$ In objecting, the states are given the choice of either simply objecting - in which case, the provision to which the reservation relates does not apply between the reserving and the objection state while the rest of the treaty does-or objecting to the entry into force of the treaty in its entirety. ${ }^{24}$ The states who wish to object shall be very attentive to the 12 -month period; if they do nothing during this period, they are considered as having accepted the reservation and have no other chance to lodge a formal objection. ${ }^{25}$ The accepted reservation thus enters into force and modifies the treaty relationships between the reserving and the accepting state to the extent of the reservation. ${ }^{26}$

This brief and formal description of the reservations regime demonstrates that within the reservations regime itself, states have only limited opportunities for interaction pre-set by the regime. In addition, there are several difficulties and uncertainties with regard to the application of the reservation regime, including the consequences of incompatible reservations, ${ }^{27}$ effects of objections to excluding as

\footnotetext{
22 ibid Art 19(c).

23 ibid Art 20(5).

${ }^{24}$ ibid Arts 20(4)(b) and 21(3).

25 ibid Art 20(5).

${ }^{26}$ ibid Art 21(1).

${ }^{27}$ See, eg, Roberto Baratta, 'Should Invalid Reservations to Human Rights Treaties be Disregarded?' (2000) 11 European Journal of International Law 423; Curtis A Bradley and Jack L Goldsmith, 'Treaties, Human Rights and Conditional Consent' (2000) 149 University of Pennsylvania Law Review 399; Ryan Goodman, 'Human Rights Treaties, Invalid Reservations, and State Consent' (2002) 96 American Journal of International Law 531; Lisbeth Lijnzaad, Reservations to UN Human Rights Treaties: Ratify and
} 
opposed to modifying reservations, ${ }^{28}$ and insufficiency of the 12 -month period. ${ }^{29}$ While the limited occasions may still allow substantively meaningful interaction between states, procedural limitations imposed by the regime combined with these difficulties, undermine the quality of interaction among states. However, as will be shown below, these limitations and difficulties have led to a significant degree of creativity in state practice. This creativity was named by the Special Rapporteur 'the reservations dialogue'. ${ }^{30}$

\section{B The Reservations Dialogue}

Ruin? (Dordrecht, M Nijhoff, 1995); Eric Neumayer, 'Qualified Ratifications: Explaining Reservations to International Human Rights Treaties’ (2007) 36 Journal of Legal Studies 397; Catherine Redgwell, 'Reservations to Treaties and Human Rights Committee General Comment no 24 (52)' (1997) 46 International and Comparative Law Quarterly 245; Brunno Simma and Gleider I Hernández, 'Legal Consequences of an Impermissible Reservation to a Human Rights Treaty: Where Do We Stand' in E Cannizzaro (ed), The Law of Treaties Beyond the Vienna Convention (Oxford, Oxford University Press, 2011) 60 .

${ }^{28}$ Massimo Coccia, 'Reservations to Multilateral Treaties on Human Rights' (1985) 15 California Western International Law Journal 34; Rebecca J Cook, 'Reservations to the Convention on the Elimination of All Forms of Discrimination Against Women' (1990) 30 Virginia Journal of International Law 656; Horn, Reservations and Interpretative Declarations to Multilateral Treaties (n 19) 182; Ruda, 'Reservations to Treaties' (n 19) 199-200.

${ }^{29}$ Greig, 'Reservations' (n 19) 118-35; Horn (n 19) 206-9; Swaine, 'Reserving' (n 19) 319.

${ }^{30}$ ILC Seventeenth Report (2011) (n 2). 
In the practices of reservations, I investigated the reservations dialogue which took many different forms. The dialogue has often been initiated by states who desired to discourage reservations in terms of their number as well as their extent. Being faced with general or imprecise reservations, the states request clarifications and precision from the states which made reservations. In response to apparently incompatible reservations, non-reserving states invite the reserving states to reconsider their reservations. In response to the inflexibility of the 12-month rule, the non-reserving states still send their opinions on reservations to the depositary so that the reserving state and other states parties can be informed about their position. In their attempt to invite the reserving state to reconsider the reservation or provide clarifications, the nonreserving states at times omit to formally object to the reservation. As will be demonstrated later, in some instances, the analysis of surrounding circumstances allows us to affirm that the so-called objecting states intentionally omit to formally object to reservations in order to avoid the inflexibility of the reservations regime. This nuanced and flexible attitude of non-reserving states is one of the key features of the reservations dialogue, as will be discussed further below. In response to the nuanced 'objection', the reserving states do not always remain silent and passive. They sometimes respond with clarifications, provide additional information, or even reconsider their reservations by modifying or partly withdrawing them. In turn, the objecting states respond creatively not only by re-expressing their objection in a nuanced way, but also by welcoming the effort made by the reserving states and by indicating that more effort would be desirable. An important role has been played in this context by some human rights treatymonitoring bodies which utilise their diplomacy in enquiring about states' reasons for making reservations, exchanging views with the reserving states on different 
possibilities for reform, and eventually leading to a partial or total withdrawal of the reservations. $^{31}$

The questions then arise as to the relationship between the reservations dialogue and the reservations regime under the Vienna Convention, and what this relationship instructs us about the reservations regime and human rights treaties and standards. In Alain Pellet's Seventeenth Report, the first part of which is devoted to the reservations dialogue, it appears clear from the outset that he tried to keep the traditional vision of the reservations regime intact. As will be demonstrated in section IV, many developments taking place in relation to the reservations dialogue challenge the traditional framework and can be interpreted as qualitatively new practices. However, the official vision of the reservations dialogue as it appears from the Seventeenth Report and the Guide to Practice underplays many of these developments.

Pellet starts by defining borders within which he will then keep his description of the reservations dialogue: 'The reservations regime instituted by the Vienna Convention does not impose static solutions on contracting States or contracting organizations; rather, it leaves room for dialogue among the key players' ${ }^{32}$ The report

\footnotetext{
${ }^{31}$ Unfortunately, the limited space of the chapter does not allow for a detailed consideration of the particular role played by treaty-monitoring bodies in the reservations dialogue. However, the internal dynamics of the reservations dialogue as it takes place with participation of the treaty-monitoring bodies is very similar to that of the reservations dialogue between states which is analysed below. Some of the most important examples will be introduced. For an interesting analysis of the role played by the CEDAW with regard to reservations, see Ekaterina Yahyaoui Krivenko, Women, Islam and International Law Within the Context of the Convention on the Elimination of All Forms of Discrimination Against Women (The Hague, Brill, 2009) 199-208.

${ }^{32}$ ILC Seventeenth Report (2011) (n 2) 2, para 2.
} 
contains two separate parts: one about the reservations dialogue within the Vienna Convention's regime (paras 8 to 27) (explained in section $\mathrm{C}$ below) and another about the reservations dialogue outside the Vienna system (paras 28 to 53) (section D).

\section{Reservations Dialogue within the Vienna Convention}

According to Pellet, the two reactions to reservations recognised by the Vienna Convention, namely, acceptance and objection, are the means of conducting the reservations dialogue. His report affirms that consequences of objections are not limited to the effects attributed to them by the Vienna Convention. The states' objections also 'may mark the beginning of cooperation between the key players'. ${ }^{33}$ Pellet continues describing how some objecting states invited the reserving state to reconsider its reservation and to provide additional information on the reservation, and how the objecting states could thereby initiate the reserving state's reflection on the reservation. In some cases, the objections may result in the withdrawal or reformulation of the reservation, although, as the Special Rapporteur himself notes, it is not always possible to establish the link between the reactions of the objecting states and the withdrawal or modification of the reservation. ${ }^{34}$

\footnotetext{
33 ibid 5 para 9.

${ }^{34}$ See, eg, his observation with regard to Malaysia's partial withdrawal of its reservations to Convention on the Elimination of All Forms of Discrimination Against Women: 'Although the link cannot been clearly established' (ibid 5 para 9) or his note with regard to Chile's withdrawal of a reservation to the
} 
Pellet also observes that a similar effect (ie, to encourage the reserving states to react to the objections, comment on them, and possibly withdraw reservations) can be produced by other reactions which do not formally qualify as objections under the Vienna Convention but which, according to him, still fall within the Vienna Convention regime. Such reactions include: objections formulated by non-contracting states, conditional objections to specified but potential or future reservations, late objections formulated after the end of the time period, and objections to incompatible reservations. $^{35}$

Pellet's description of the reservations dialogue within the Vienna Convention regime makes clear that any positive effects of the reservations dialogue within the Vienna Convention are achieved, not because of the legal effects attributed to various reactions of states by the Vienna Convention, but for other incidental reasons that are not examined in detail in the report. The Special Rapporteur simply notes that number and consistency of objections would play a significant role, ${ }^{36}$ as does the concerted way of expressing opinion on reservations. ${ }^{37}$ I will examine some of these incidental reasons later, using examples from state practice (section IV(B)) I will demonstrate that the understanding of these reasons and motivations is fundamental for the potential creation of enhanced efficiency of the reservations dialogue within the context of promotion of the rule of law.

Convention Against Torture: 'The political changes that took place in Chile in the early 1990s probably encouraged withdrawal of the reservation formulated in 1988' (ibid 11 note 37).

${ }^{35}$ ILC Seventeenth Report (2011) (n 2) 7 paras $14 \mathrm{ff}$.

${ }^{36}$ ibid 13 para 22.

${ }^{37}$ ibid 14 para 25. 


\section{Reservations Dialogue outside the Vienna Convention}

Pellet discussed two groups of reactions which, according to him, fall outside the Vienna Convention regime: (1) contracting states/orgnisations' reactions other than objections and acceptance; ${ }^{38}$ and (2) reactions of treaty-monitoring bodies and international organisations. ${ }^{39}$ The placing of this latter type of reservations dialogue outside the Vienna Convention regime is not contested: the Vienna Convention does not envisage either the existence of treaty-monitoring bodies or the interventions from international organisations. However, the reasons for situating the former group of reactions outside the Vienna Convention regime are less straightforward. This is because the effect and role of the reactions in the former group would be, in fact, very similar to those of 'other reactions' (eg, objections formulated by non-contracting states) discussed above in section $\mathrm{C}$ which are placed within the Vienna Convention regime.

For example, the Special Rapporteur places outside the Vienna Convention regime 'undefined reactions which do not reveal their purpose and complaints about

\footnotetext{
${ }^{38}$ ibid paras $30-38$.

39 ibid paras 39-53. This second aspect of the reservations dialogue outside of the Vienna Convention is not discussed further because, as stated previously (n 31), the limited space of the chapter does not allow for consideration of the role of treaty-monitoring bodies in the reservations dialogue.
} 
reservations'. ${ }^{40}$ He even affirms that these undefined reactions and complaints 'serve little purpose' ${ }^{41}$ Yet, at least in terms of legal effect, it is difficult to distinguish these imprecise reactions from, for instance, the late objections which are categorised by Pellet as the reservations dialogue within the Vienna Convention regime. Also, the practical effects of the imprecise statements are exactly the same as that of late objections: partial or total withdrawals of reservations. It seems that the distinction between inside and outside of the Vienna Convention regime serves the purpose of preparing the ground for maintenance of the status quo and avoiding any modifications to the Vienna Convention regime. The relatively conservative attitude of the Special Rapporteur is confirmed by his conclusions and proposals. Although he insists that the reservations dialogue is a valuable practice, he abstains from proposing any specific draft guideline on the reservations dialogue. He simply recalls that some previously adopted draft guidelines recommending that states adopt certain practices with regard to reservations and objections are sufficient indicators of the ILC's support of the reservations dialogue. ${ }^{42}$ Pellet also formulates draft recommendations or conclusions on the reservations dialogue which use language different from the language used in the main text of the draft guidelines. These conclusions do not form part of the Guide to

\footnotetext{
${ }^{40}$ ibid para 31. Pellet puts into this group all reactions to reservations that do not express an objection to a reservation stricto sensu. The examples are discussed in paras 30-38 of the report.

${ }^{41}$ ibid.

${ }^{42}$ Thus, he points out the draft guidelines 2.1.9 (became 2.1.2) encouraging states to indicate reasons for their reservations (ibid para 58); the draft guideline 2.6.10 (became 2.6.9) encouraging states to do the same with regard to their objections (para 59); the draft guideline 4.5.3 (became 4.5.2, paragraph 2) encouraging states to formulate objections to invalid reservations (para 60); and finally, the draft guideline 2.5.3 encouraging periodic review of reservations with a view of withdrawing them either partially or totally (para 61).
} 
Practice itself but are included as an annex to it. Overall, despite ILC's 'welcoming the efforts ... to encourage such a dialogue', ${ }^{43}$ the dialogue appears to have been pushed into its periphery, rather than into the core of the reservations regime.

\section{Re-imagining the Reservations Dialogue}

The previous section presented the dynamics of the reservations dialogue in general, as they appear through the reading of the report presented by the Special Rapporteur and reflected in the Guide to Practice. The present section aims at putting the practices of the reservations dialogue into a new light. For this purpose, I will present the context within which the reservations dialogue has been developing, and demonstrate the prevalence of human rights treaties in the development of the reservations dialogue (section A). I will then analyse in detail the practice of the reservation dialogue as it developed within the context of the Convention on the Elimination of All Forms of Discrimination Against Women (ICEDAW) (section B). ${ }^{44}$ This convention is chosen because, as will be demonstrated below, it is a single treaty that produced the majority of instances of the reservation dialogue.

\footnotetext{
${ }^{43}$ Report of the International Law Commission Guide to Practice (2011) (n 2) Annex, last para of the preamble.

${ }^{44}$ Convention on the Elimination of All Forms of Discrimination against Women, 18 Dec 1979, 1249 UNTS 13.
} 


\section{A Context of the Reservations Dialogue}

The distinguishing feature of the reservations dialogue is obviously its dialogical nature. Such a feature is significant and unique, especially given that the Vienna Convention regime, in the context of which the reservations dialogue develops, is characterised by preference for definite and statist solutions. As explained above, under the Vienna Convention, the reservations regime was designed in quite a formalistic way. Despite the Special Rapporteur's affirmation that the Vienna Convention does not impose 'static solutions', ${ }^{45}$ the drafters of the Vienna Convention may not have envisaged the reservations regime as a dialogue. The reservations regime was conceived as a means of allowing as many states as possible to become parties to a treaty while preserving the centrality of the notion of state consent and the appearance that all parties to a treaty (whether reserving or not) are bound only by what they consented to.

Yet the formalistic traditional logic of the reservations regime is often unable to account for the dynamics of the reservations dialogue. For instance, the traditional framework may not appropriately account for why an objecting state should engage in any discussions about the extent and nature of a particular reservation if this objecting state's position and interests can be preserved by simply formulating an objection. The reservations regime of the Vienna Convention allows any objecting state desiring to

\footnotetext{
${ }^{45}$ See (n 32) and accompanying text.
} 
preserve its interests to go as far as to exclude any treaty relationships between itself and the reserving state; yet the reality is that many states still prefer other types of reactions not envisaged by the Vienna Convention to this extreme form of objection. Also, the traditional logic does not sufficiently explain why states, which complain about the lack of resources and insufficiency of time limit rule should, first, formulate such detailed objections and engage in any dialogue; second, from the point of view of reserving states, respond to these objections; and, finally, again from the point of view of objecting states, continue to respond to modified reservations, knowing that all this has no legal effects stricto sensu.

In order to understand these dynamics and motives of states, we need first to take a closer look at the context within which the reservations dialogue takes place in practice. As is already evident from the practices referred to by the Seventeenth Report of the Special Rapporteur, the majority of instances of the reservations dialogue take place within the framework of human rights treaties. The table below contains the number of instances relating to reservations dialogue ${ }^{46}$ for different types of treaties mentioned in the report. I distinguish three types of treaties: human rights treaties, nonhuman rights treaties, and an intermediate category of treaties related to human rights and humanitarian affairs. The category of human rights treaties is based on the contents of the Chapter IV of the Collection of Multilateral Treaties Deposited with the Secretary

\footnotetext{
${ }^{46}$ In this context, the 'instances' refer to any occurrence identified by the Special Rapporteur as an example of the reservations dialogue. Such instances include a particular objection, reservation, or other reaction. The objection, reservation, and other reactions are counted as different 'instances' if they concern different treaties; on the other hand, they are counted as one 'instance' if they concern different states within the same treaty.
} 
General as of May 2013. ${ }^{47}$ The meaning of each abbreviation is provided in footnotes. I created the intermediate category for those treaties which are not contained in Chapter IV of the Collection but still concern human rights and humanitarian affairs. ${ }^{48}$ Finally, while some treaties do not deal with human rights and are thus included in the category of non-human rights treaties, they may still contain provisions of humanitarian or human rights spirit and the reservations dialogue could be developing around these provisions.

Table 1

\begin{tabular}{|l|lr|r|}
\hline Type of Treaties & $\begin{array}{l}\text { Number of } \\
\text { Instances }\end{array}$ & Percentage \\
\hline Human Rights & & 26 & $62 \%$ \\
ICEDAW $^{49}$ & 10 & \\
\hline
\end{tabular}

\footnotetext{
${ }^{47}$ An online version is available at: http://treaties.un.org/Pages/ParticipationStatus.aspx. The only human rights treaty not mentioned in this Chapter IV but included in the table is the European Convention on Human Rights. However, the 'human rights' nature of this regional treaty is undisputed.

${ }^{48}$ The following treaties used in the Seventeenth Report are included into this category (the number in parenthesis indicates the number of instances for each particular treaty): UN Convention against Illicit Trafficking in Narcotic Drugs and Psychotropic Substances, 20 Dec 1988, 1582 UNTS 95 (1); International Convention for the Suppression of Terrorist Bombings, 15 Dec 1997, 2149 UNTS 256 (1); International Convention for the Suppression of the Financing of Terrorism, 9 Dec 1999, 2178 UNTS 197 (2); Convention on the Environmental Impact Assessment in a Transboundary Context, 25 February 1991, 1989 UNTS 309 (1); Protocol III to the Convention on Prohibitions or Restrictions on the Use of Certain Conventional Weapons Which May Be Deemed to be Excessively Injurious or to Have Indiscriminate Effect, 10 Oct 1980, 1342 UNTS 137 (2); Rome Statute of the International Criminal Court, 17 July 1998, 2187 UNTS 3 (1); Additional Protocol III to the Geneva Conventions of 1949, 8 Dec 2005, Notification of the Federal Department of Foreign Affairs of Switzerland, Bern, 4 Jan 2006 (1).

${ }^{49}$ Convention on Discrimination against Women (n 44).
} 


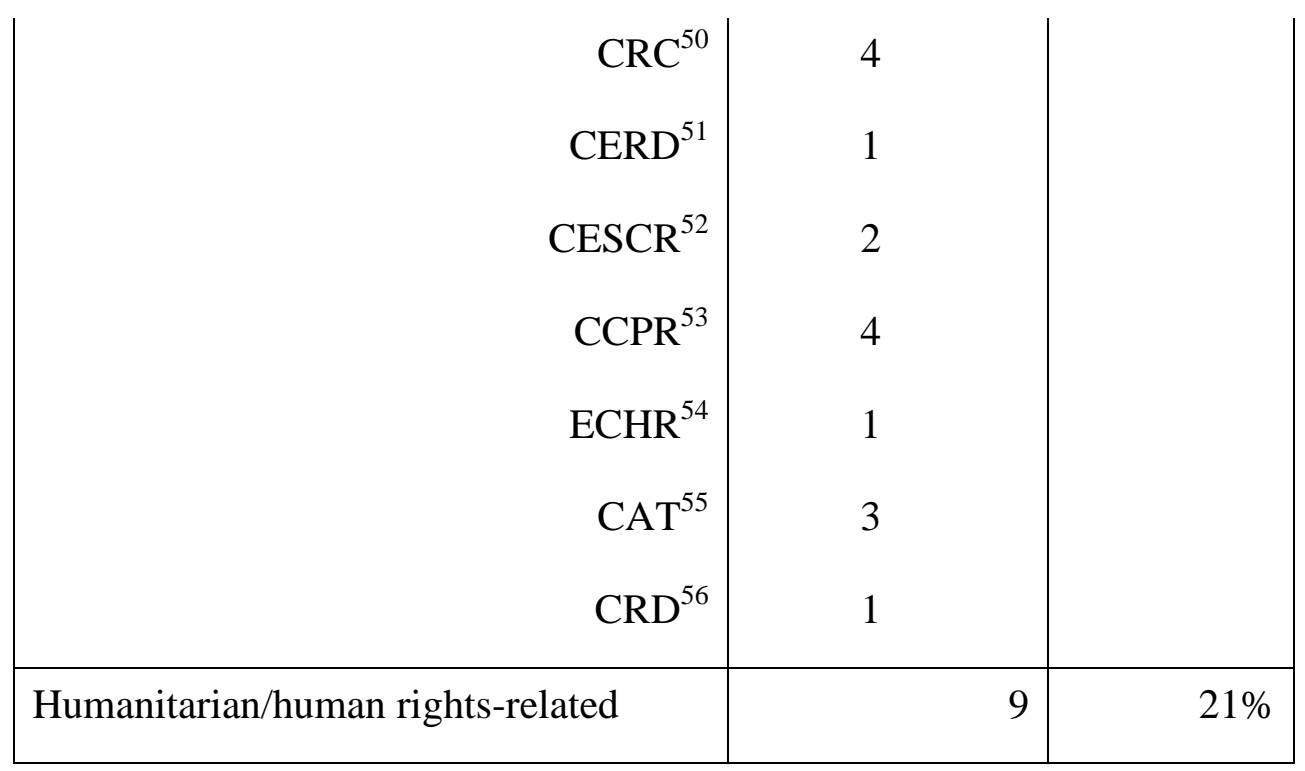

${ }^{50}$ Convention on the Rights of the Child, 20 Nov 1989, 1577 UNTS 3.

${ }^{51}$ International Convention on the Elimination of All Forms of Racial Discrimination, 21 Dec 1965, 660 UNTS 195.

${ }^{52}$ International Covenant on Economic, Social and Cultural Rights, 16 Decr 1966, 993 UNTS 31.

${ }^{53}$ International Covenant on Civil and Political Rights, 16 Dec 1966, 999 UNTS 171 (1966).

${ }^{54}$ Convention for the Protection of Human Rights and Fundamental Freedoms, 4 Nov 1950, ETS 5, 213 UNTS 221 (1950).

${ }^{55}$ Convention against Torture and Other Cruel, Inhuman or Degrading Treatment or Punishment, 10 Dec 1984, 1465 UNTS 85.

${ }^{56}$ Convention on the Rights of Persons with Disabilities, 13 Dec 2006, 2515 UNTS 3 


\begin{tabular}{|l|r|r|}
\hline Non-human rights $^{57}$ & 7 & $17 \%$ \\
\hline \hline Total & 42 & $100 \%$ \\
\hline
\end{tabular}

This table clearly demonstrates that the reservations dialogue is the most active within the context of human rights treaties (ie, 62 per cent of the practices).

One of the possible reasons human rights treaties predominate in the practice of the reservations dialogue is that the reservations dialogue develops when states are faced with most serious challenges to human rights standards. The review of the examples used in the Seventeenth Report reveals the interesting pattern that the majority of instances of the reservations dialogue involve Muslim majority states and discussion around reservations linked to various degrees to application of Islamic laws in these countries. The reservations dialogue has been utilised as a tool to address the core difficulties surrounding the international rule of law and its relationship with international human rights as well as the relationship between divergent understandings of the rule of law emerging within the domestic and the international spheres.

\footnotetext{
${ }^{57}$ The following treaties are concerned (the number in parenthesis indicates the number of instances for each particular treaty): Inter-American Treaty of Reciprocal Assistance, 2 Sept 1947, OAS Treaty Series nos 8 and 61 (1); Charter of the Organization of American States, 30 April 1948, OAS Treaty Series, nos 1C and 61 (1); Agreement on the International Carriage of Perishable Foodstuffs and on the Special Equipment, 1 Sept 1970, 1028 UNTS 121 (1); Vienna Convention on the Law of Treaties, 25 May 1969, 1155 UNTS 331 (1); Geneva Convention on the Territorial Sea and the Contiguous Zone, 29 April 1958, 516 UNTS 205 and the Geneva Convention on the Continental Shelf, 29 April 1958, 499 UNTS 311 (1: both Conventions are mentioned as one instance in the Seventeenth Report because they concern an identical reservation made by the same state); Vienna Convention on Consular Relations, 24 April 1963, 596 UNTS 261 (1); Vienna Convention on Diplomatic Relations, 18 April 1961, 500 UNTS 95 (1).
} 
Among human rights treaties, ICEDAW ${ }^{58}$ has generated more instances of the reservations dialogue than all other treaties, which makes it worth elaborating further on the practice developed by states within the context of this treaty.

\section{B Substance of the Reservations Dialogue}

When taking a closer look at the state practice with regard to reservations, a broader view of 'reservations dialogue' is emerging. The view helps us to realise, not only the artificial character of the distinction between 'inside' and 'outside' of the Vienna Convention, but also the significance of non-legal consequences of reactions that, according to the Seventeenth Report, 'serve little purpose'. ${ }^{59}$ We also understand the importance of the role played by treaty-monitoring bodies. In order to demonstrate these implications of state practice that support the broader view of the reservations regime, I will draw on the practices relating to the ICEDAW. The practices are divided into four groups: (1) reactions to reservations which states deemed incompatible; (2) reactions dealing with the impact of reservations on reserving states' human rights obligations; (3) reactions to reservations expressed after the expiry of the 12-month time limit, and (4) responses of reserving states to objections and other reactions to their reservations.

\footnotetext{
${ }^{58}$ Convention on Discrimination against Women ( $\left.\mathrm{n} 44\right)$. All reservations, objections, and other reactions to reservations discussed here are at the corresponding page of the UN Treaty Collection website, available at: http://treaties.un.org/pages/ViewDetails.aspx?src=TREATY\&mtdsg_no=IV8\&chapter=4\&lang=en. The latest official printed version dates 2009: UN, 'Multilateral Treaties Deposited With the Secretary-General' ST/LEG/SER.E/26 (status as at 1 April 2009).

${ }^{59}$ See (n 41) above.
} 
The first two groups are based on the substance of issues addressed by states, while the two next groups are based on particular types of reactions that do not fit into the categories of the Vienna Convention regime. The third and fourth group of reactions will be analysed together because of the close links they entertain.

It is important to emphasise the following preliminary observation: in all groups of practices that will be discussed below, states express their views on reservations and clarify some aspects of the reservations regime without really objecting to reservations. This is a very peculiar stance, taking into account the often expressed contention that the 12-month period is insufficient for many states for formulating objections. What happens in the series of examples presented below is that even when states react within the 12-month period, they find it more important to express their views on the reservations and uncertainties of the reservations regime than to express a formal objection.

\section{i Reactions to Reservations Deemed Incompatible}

States are not always certain as to whether a particular reservation is compatible with the object and purpose of the treaty. The uncertainty is augmented by the fact that the Vienna Convention regime left unresolved the issue of consequences of incompatible

reservations. ${ }^{60}$ When reacting to reservations, states tend to use the objections as an

\footnotetext{
${ }^{60}$ For discussions on this issue, see references in (n 27) above.
} 
opportunity to clarify the nature of the reservation and the legal consequences of this reservation, should it be considered incompatible.

For instance, Denmark made the following statement with regard to the Libyan initial reservation. This statement was included by the depositary in the text of objections:

The Government of Denmark has taken note of the reservation made by the Libyan Arab Jamahiriya when acceding [to the said Convention]. In the view of the Government of Denmark this reservation is subject to the general principle of treaty interpretation according to which a party may not invoke the provisions of its internal law as justification for failure to perform a treaty. ${ }^{61}$

This statement simply acknowledges the existence of the reservation and reminds the reserving state about a general rule of treaty law that is supposed to be known by all states. However, this statement does not constitute a formal objection. It could rather be interpreted as an indirect expression of the state's opinion about the nature of the reservation. Other reactions of states to reservations would also contain explanations about why a particular state regards a specific reservation as potentially incompatible with the object and purpose of the treaty without, however, making a final authoritative statement. They would rather suggest that the reservation 'creates doubts' as to the commitment of the reserving state. ${ }^{62}$ Alternatively, some objecting states

\footnotetext{
${ }^{61}$ UN Multilateral Treaties (2009) (n 58) 309.

${ }^{62}$ See objections of Norway to the reservations by the Maldives, Kuwait, and Pakistan. For some reasons, the objections of Norway are not listed in the latest 2009 edition of Multilateral Treaties; for an official
} 
would invite the reserving state either to provide additional information or proof through subsequent practice that the reservation is not incompatible. ${ }^{63}$

As far as uncertain consequences of incompatible reservations are concerned, many states choose to express their opinion on this issue in their reactions to reservations (be they formal objections or other types of statements). Many states emphasised that the particular reservation deemed to be incompatible 'cannot alter or modify in any respect the obligations arising from the Convention for any State Party thereto'. ${ }^{64}$

\section{ii Reactions Dealing with Impact of Reservations on Reserving States' Human Rights Obligations}

Another interesting group of reactions to reservations is constituted by objections and other statements which clarify one or another aspect of the relationship between the reservations regime and existing human rights treaty obligations. Several states included

reference, see the 2006 edition ST/LEG/SER.E/25 (31 Dec 2006) 278. See also Austria's objection to the reservation of Pakistan: UN Multilateral Treaties (2009), ibid 306.

${ }^{63}$ Austria's objection to the reservation by Pakistan: ibid.

${ }^{64}$ See statements made by Austria with regard to the reservation of the Maldives (UN Multilateral Treaties (2009), ibid 305); Finland with regard to reservations of Bahrain, Kuwait, Malaysia, Mauritania, Niger, Pakistan, Saudi Arabia, and Syria (ibid 312-14); Norway with regard to reservations of Niger, Mauritania, Saudi Arabia; Portugal with regard to reservations of the Maldives (ibid 326-27); and Sweden with regard to reservations of Bahrain, Mauritania, Saudi Arabia, and Syria (ibid 331-33). 
statements indicating that the reserving state is already a party to human rights conventions protecting rights similar to those it attempts to reserve. Moreover, they also stress that these rights are also protected in virtue of customary law. Therefore, the reserving state is not entitled to make the reservation. ${ }^{65}$

In order to understand these types of statements, the Vienna Convention regime on its own is insufficient. The Vienna Convention regime was designed to bring into the international treaty law the balance between the universality of participation and integrity of a treaty by preserving at the same time the fundamental principle that states cannot be bound without their consent. ${ }^{66}$ The drafters of the Vienna Convention could not have imagined that states in reacting to reservations would express their opinions on the reservations regime itself or discuss the nature of the reservation with the reserving state. In attempting to subsume these statements under the Vienna Convention regime, the Special Rapporteur missed the opportunity to favour a more innovative and farreaching development. The mandate of the Special Rapporteur was defined quite broadly ${ }^{67}$ and allowed him to engage in both a broader reading of the Vienna

\footnotetext{
${ }^{65}$ See statements made by Mexico with regard to reservations of Bangladesh, Egypt, Iraq, and Libya (Multilateral Treaties (2009), ibid 322); Sweden with regard to reservations of Bahrain, Bangladesh, Tunisia, Egypt, Iraq, Libya, Jordan, the Maldives, Kuwait, and Syria (ibid 331-32); and Denmark with regard to the reservation of Syria (ibid 310).

${ }^{66}$ See, eg, Second Report of Alain Pellet UN Doc A/CN.4/477/Add 1 (13 June 1996) 16-18, paras 90-98. A similar view was also expressed by the International Court of Justice already in 1951: Reservations to the Convention on Genocide [1951] ICJ Reports 15 (Advisory Opinion of 28 May 1951) esp 24-26.

${ }^{67}$ See the title of the mandate: 'Law and Practice Relating to Reservations to Treaties' and the way this topic was introduced into the ILC's work: Report of the International Law Commission on the Work of its Forty-Fifth Session (1993) Yearbook of the International Law Commission, vol 2, pt 2, at 96, paras 42830 .
} 
Convention regime itself and development of a reading of the reservations regime going beyond the confines of the Vienna Convention. According to my interpretation of the part of his report related to the reservations dialogue, he has taken neither of these routes.

Before analysing further the implications of such statements beyond the Vienna Convention regime, it is important to recall two other practices relevant to the reservations dialogue: reactions after the expiry of the 12-month period and responses of reserving states.

\section{iii Reactions to Reservations after the Expiry of the 12-Month Period and Responses of Reserving States}

Many states reacted to reservations after the expiration of the 12-month period. These reactions can be divided into two groups. First, some of these reactions can be regarded as motivated by the desire of states to catch up the missed time because they were not able to object within the prescribed 12-month time limit. ${ }^{68}$ This type of late reactions is

\footnotetext{
${ }^{68}$ These types of reactions will contain such words as 'objection', 'object', etc. See, eg, the French communication sent in response to the reservation of Niger where the French government even attempted to persuade the depositary that the time limit did not yet elapse: UN Multilateral Treaties (2009) (n 58) 344. See also communications by Denmark to the reservation of Kuwait (Multilateral Treaties (2009), ibid note 30, 340-41), communication of Portugal to the reservation of Pakistan (Multilateral Treaties (2009), ibid 344, note 49). It should be noted that when the reaction of the state is submitted after the time limit but does not have as its primary purpose to object to the reservation, simply making a statement about the reservation, the depositary labels it 'notification'.
} 
less significant for the purposes of present analysis, but demonstrates that the 12-month time limit rule presents a real problem for some states. More significant is the second group of reactions where states reacting to reservations are not at all concerned with the 12-month time limit rule. The only real motivation for them was the desire to express their view on the reservations. As with the previously mentioned reactions to reservations made within the prescribed time limit but without containing a formal objection, these statements are even less subsumable under the reservations regime. In order to understand their real implications, we need to analyse them from a broader perspective.

At the following stage of the reservations dialogue some reserving states provide responses to the requests they received from reacting states. Although direct responses to concrete inquiries are relatively rare, they do exist and evidence the emergence of a new trend. ${ }^{69}$ In other instances the responses are more indirect and take the form of partial withdrawals or reformulations of reservations. Within this category of responses, the 'dialogical' nature can be easily established in some cases, while in other cases there is little evidence as to the precise reasons for withdrawal or modification.

For example, the sequence of events which led to the first partial withdrawal of Malaysia's initial reservation described below clearly indicates the role which

\footnotetext{
${ }^{69} \mathrm{See}$, eg, response of Syria to the objection of Germany provided on 6 May 1996 within the context of the Convention on the Rights of the Child (n 50) 3. The response is contained in the note 52 of the status of the Convention, available at:
} http://treaties.un.org/pages/ViewDetails.aspx?src=TREATY\&mtdsg_no=IV$11 \&$ chapter=4\&lang=en\#EndDec. 
objections played in the process as well as the fact that Malaysia acted 'in response' to these objections.

Finally, in some cases, the dialogue continues and states react even to these modified or partially withdrawn reservations. These reactions can never fit into the framework of the reservations regime because it does not provide for the possibility to object to a partially withdrawn reservation. ${ }^{70}$ However, they are fundamental for a deeper understanding of the reservations dialogue and its reading articulated below. Therefore, I will reproduce the full text of the two of these reactions.

In response to the proposed partial withdrawal and modification of the reservation by Malaysia, the government of The Netherlands declared:

The Government of the Kingdom of the Netherlands has examined the modification of the reservations made by Malaysia to article 5(a) and 16.1. (a) and paragraph 2 of the [Convention]. The Government of the Kingdom of the Netherlands acknowledges that Malaysia has specified these reservations, made at the time of its accession to the Convention. Nevertheless the Government of the Kingdom of the Netherlands wishes to declare that it assumes that Malaysia will ensure implementation of the rights enshrined in the above articles and will strive to bring its relevant national legislation into conformity with the obligations imposed by the Convention. This declaration shall not preclude the

\footnotetext{
${ }^{70}$ This situation is maintained in the Guide to Practice: Rule 2.5.7 and 2.5.11. I emphasised the illogical nature of this solution, especially as far as states which objected to the initial reservations are concerned. States that objected to the initial reservation might legitimately still have some objections to the partially withdrawn reservation, but the Vienna Convention regime does not allow for expression of objections or any other reactions at this stage. See Yahyaoui Krivenko, Women, Islam and International Law (n 31) 93-94.
} 
entry into force of the Convention between the Kingdom of the Netherlands and Malaysia. $^{71}$

Very similar in nature was the reaction of Finland to the proposed modification of the reservation by Maldives:

The Government of Finland welcomes with satisfaction that the Government of the Republic of Maldives has specified the reservations made at the time of its accession to the Convention. However, the reservations to Article 7 (a) and Article 16 still include elements which are objectionable. The Government of Finland therefore wishes to declare that it assumes that the Government of the Republic of Maldives will ensure the implementation of the rights recognised in the Convention and will do its utmost to bring its national legislation into compliance with obligations under the Convention with a view to withdrawing the reservation. This declaration does not preclude the entry into force of the Convention between the Maldives and Finland. ${ }^{72}$

These two statements adopt a very cautious language: they emphasise the positive aspects of the effort made by governments in attempting to revise the reservation and express faith in the fact that the government will respect the Convention. While they note that additional efforts are required to bring the situation in these states into full conformity with the provisions of the Convention, they do not formally object to any part of the modified reservations. Finland's reaction simply states that there are still 'elements which are objectionable'. The Netherlands indicates the same idea by using

\footnotetext{
${ }^{71}$ UN Multilateral Treaties (2009) (n 58) 342, note 35.

72 ibid 342, note 36 .
} 
'nevertheless' after acknowledging the effort made by the Malaysian government. However, they also use the opportunity to remind reserving states about their expectations (and expectations of many other states) concerning the fulfilment of international obligations.

What clearly emerges from this brief description of the reservations dialogue as it took place within the context of the ICEDAW is its broader scope going clearly beyond the reservations regime. In order to discover its full potential and significance, it is necessary to read this exchange between states that are party to a convention beyond the Vienna Convention regime. One such reading is proposed below.

\section{The Reservations Dialogue as an Interface between the Domestic and the International Rule of Law}

The exchange taking place within the framework of the reservations dialogue has a distinct negotiative nature. The subject matter of the negotiation is not always obvious. The apparent subject matter of the reservation is not always the only issue negotiated. The dialogue could also have an impact on related but unstated matters.

Within the context of the ICEDAW, the dialogue broadly raises three main issues: first, the rules of the reservations regime itself; second, the nature of the states' human rights obligations, including the relationship between various types of 
obligations; and, third, the substantive content of states' human rights obligations, especially from the point of view of each particular state's domestic laws. At first sight, the latter set of issues appears as the most important for the purposes of understanding the relationship between domestic and international rule of law. However, the overall attitude of states with regard to all issues is equally significant.

In this negotiative process, brought into being by the reservations dialogue, a particular image of international law emerges. International law appears as an arena where values proposed as candidates for universal acceptance are negotiated, where mechanisms to assist states with implementation of these newly negotiated values are created. It is important to realise that, although the text of adopted human rights treaties contains some rules and definitions pretending to have a universal validity, the reality is that many of these rules and values are too general to be interpreted uniformly. Moreover, far from being universal, they are often an expression of a consensus reached by states participating in the drafting process only. The reservations dialogue and the following discussion, also mediated by a treaty-monitoring body, allow not only the clarification of the content of the rules, but also the taking into account of opinions and positions of a variety of states and other actors (NGOs), thus universalising a particular rule or value and conveying to it a required degree of legitimacy. The input from domestic law of various countries plays a crucial role in this process. While the domestic law as such does not become a part of the international law and does not modify the text or wording of the rule, it leaves a mark on the international law which will influence the operation of the international rule and allow it, in turn, to be more demanding on non-compliant domestic law. 


\section{A Impact of the Domestic Law on the Negotiation of Universal Values}

In order to illustrate this point, I will turn to some examples related to the discussion of various Islamic family laws within the context of the ICEDAW. The fact that many Muslim states entered several general reservations to the ICEDAW in order to protect the application of Islam-inspired family laws has often been viewed as one of the major negative trends in the implementation of the ICEDAW. ${ }^{73}$ The reservations dialogue evolved very actively around this issue between states and the Committee on the Elimination of Discrimination against Women (CEDAW), which has so far adopted a particular attitude toward state reports.

The Committee would normally ask many questions for clarification in an attempt to understand the operation of domestic law in the relevant states. ${ }^{74}$ It also uses the insights gained during the examination of a state's reports as a tool for suggesting

\footnotetext{
${ }^{73}$ This concern has been voiced very early and only with regard to reservations based on Islam, although other states also entered similar reservations motivated by their culture/tradition. See, eg, Michele Brandt and Jeffery A Kaplan, 'The Tension Between Women's Rights and Religious Rights: Reservations to CEDAW by Egypt, Bangladesh and Tunisia' (1995) 12 Journal of Law and Religion 105; Rebecca J Cook, 'Reservations to the Convention on the Elimination of All Forms of Discrimination against Women' (1990) 30 Virginia Journal of International Law 643.

${ }^{74} \mathrm{eg}$, during the discussion about a particular type of divorce which appears to be discriminatory against women and thus to be an obstacle to the withdrawal of Egypt's reservation but which is presented as constituting an advancement in the field of women's rights by Egyptian representatives, one member of the Committee said that 'It would be helpful to see documentation of exactly how khula divorce was administered in practice'. Committee on the Elimination of Discrimination Against Women, Forty-fifth session, Summary records of the 919th meeting, CEDAW/C/SR.919 (2010) 6, para 31.
} 
possible ways of improvement for other states. ${ }^{75}$ For example, during the examination of the initial report of Libya, one of the members stated that 'she did not see why those reservations should be upheld out of respect for Shari'a, when the report had emphasised the pioneering role the Shari'a had played in promoting women's rights' ${ }^{76}$ This attitude of the Committee prompted Libya to give more explanations about the precise operation of Islamic law, thus demonstrating how its domestic law confirms to the rights codified in the Convention. These explanations, in turn, give the Committee members a better understanding of the operation of international human rights standards in particular domestic contexts and also a sense of how these rules are interpreted by particular states, thus allowing it to develop an interpretation which is as inclusive possible.

The example of interactions between Libya and the Committee suggests that the reservation dialogue could become a channel through which diversity is negotiated, and

\footnotetext{
${ }^{75}$ See, eg, the following observation made by one of the Committee members during the examination of combined third and fourth periodic reports of Kuwait: "she suggested that the approaches adopted by other Arab nations that had succeeded in withdrawing sharia-based reservations might be studied for guidance.' Committee on the Elimination of Discrimination Against Women, Fiftieth Session, Summary records of the 1011th meeting, CEDAW/C/SR.1011, para 6, p 2; or the statement made during the examination of the combined sixth and seventh periodic report of Egypt in relation to this country's reservations: 'She was aware of the complexities involved; similar issues arose in her own country with regard to Jewish law. The Committee had heard from a neighbouring Middle Eastern country of a very interesting review of family and personal status laws, which was being conducted in cooperation with the Grand Mufti and women's non-governmental organizations'. Committee on the Elimination of Discrimination Against Women, Forty-fifth Session, Summary records of the 918th meeting, CEDAW/C/SR.918 (2010) 3-4, para 19.

${ }^{76}$ Consideration of the initial report by Libya, Committee on the Elimination of Discrimination Against Women, Thirteenth Session, Summary records of the 237th meeting, CEDAW/C/SR.237 (1994) para 52.
} 
ultimately absorbed into universal values protected by human rights treaties. The universal values will, in turn, shape the international and the domestic rule of law. The reservations dialogue and the reservations regime generally are there to strike a balance between universality and diversity but not in the traditionally conceived way. What occurs within the reservations dialogue and the reservations regime is not a static phenomenon, but a process in which the making of the reservation is just the starting point. The process does not end with the expiration of the 12-month time limit. It continues all the way forward. Whether or not this process would contain meaningful interactions between a reserving state and the Committee would also determine whether there is a mutually beneficial interaction between the domestic and international rule of law. The success is understood as a capacity of the negotiative process to generate consensus at given point in time (substantive aspect) as well as an always-open possibility for further constructive interaction and dialogue to renegotiate the previously established consensus (procedural aspect).

\section{B Conditions for Constructive Dialogue}

In order for this success to transpire, there is a need to sustain appropriate conditions for constructive dialogue. The reservations dialogue should be understood and interpreted more broadly than what is presented in the report of the Special Rapporteur. The value of exchanges taking place outside of the Vienna Convention regime should be recognised and supported. Possibility for reaction beyond 12 months, especially if there is a suspicion that the reservation might be incompatible with the object and purpose 
should be offered. Similarly, states should be able and encouraged to react to proposed modifications of reservations without running a danger of preventing the entry into force of a positive modification. The reservations dialogue should also promote replies from reserving states.

One of the most important aspects of the reservations dialogue which needs to be preserved and cultivated is an open and dialogical attitude of all participants. In order to understand how this can achieved, I use the following example analysed through the prism of a theory formulated in the context of understanding the constitution-making processes. John Elster, writing about constitution-making processes, observes:

There is one particular passion that has, somewhat surprisingly, played a considerable role in constitution-making. This is vanity or self-love, amourpropre, which many moralists from La Rochefoucauld onwards have considered the most powerful human emotion. ${ }^{77}$

Thus, public discussion or debates, especially if they involve commitment, tend to encourage stubbornness because vanity might prevent states from changing their minds. Once a state has adopted a particular stance, representing itself as a state protecting certain cultural, religious, or other values, it is difficult to persuade this state

\footnotetext{
${ }^{77}$ Jon Elster, 'Forces and Mechanisms in the Constitution-Making Process' (1995) 45 Duke Law Journal 364, 384. This issue is also discussed in Jon Elster, 'Ways of Constitution-Making' in A Hadenius (ed), Democracy's Victory and Crisis (Cambridge, Cambridge University Press, 1997) 123, 131ff. For analysis of the reservations dialogue from a constitution-making perspective, see Ekaterina Yahyaoui Krivenko, 'The "Reservations Dialogue" as a Constitution-Making Process' (2013) 15 International Community Law Review 381.
} 
to change its position based on the critique of its values except when a state's selfidentification with particular values changes, which is not a very common phenomenon. ${ }^{78}$ In the context of the reservations dialogue all discussion is public. Therefore, the aim of bringing about a change or a modification in the position of reserving states can only be successful if it attempts to constructively engage with the values a particular state attempts to protect through the reservation, rather than criticising the values and the stance of the state. In this sense, the formalities of the Vienna Convention reservation regime do not encourage constructive dialogue and negotiation but tend to produce more stubbornness. The flexible nature of the reservations dialogue as reflected in the state practice opens ways for such a constructive discussion which will not deter states from changing their positions. The danger in attempting to put the reservations dialogue back into the framework of the reservations regime is that opportunities for such an open and constructive public discussion will become almost non-existent. A very telling example in this regard is the situation around Malaysia's attempted modification of its initial reservation.

When accessing to the ICEDAW on 5 July 1995, Malaysia formulated a reservation. ${ }^{79}$ This reservation attracted a few reactions and objections from other states

\footnotetext{
78 This change in the self-identification of the state is not impossible. The examples include regime change and change in foreign policy orientations, in the importance of values for states' international relations.

79 This reservation reads as follows: 'The Government of Malaysia declares that Malaysia's accession is subject to the understanding that the provisions of the Convention do not conflict with the provisions of the Islamic Sharia' law and the Federal Constitution of Malaysia. With regards thereto, further, the Government of Malaysia does not consider itself bound by the provisions of articles 2(f), 5(a), 7(b), 9 and 16 of the aforesaid Convention. In relation to article 11, Malaysia interprets the provisions of this article
} 
parties. ${ }^{80}$ These reactions emphasised, among others, the general and unspecified nature of the reservation, which does not allow other states parties to understand the degree of Malaysia's commitment to the Convention. They also criticised a general and unqualified reference to national laws without any further information as well as reference to some central articles of the ICEDAW. On 6 February 1998, relatively rapidly for the treaty-related context, the government of Malaysia responded to these comments made by objecting states and proposed to partially withdraw the reservation while providing a clarification for remaining reservations. ${ }^{81}$ The depositary of the ICEDAW, for some reason, did not regard this act of the Malaysian government as a partial withdrawal of reservations but as a modification comparable to a late formulation of a reservation. One of the explanations for this confusion could be the details provided by Malaysia on some of the pre-existing reservations. This wrong qualification of the

as a reference to the prohibition of discrimination on the basis of equality between men and women only'. Multilateral Treaties (n 58) 290-91.

${ }^{80}$ Finland, Germany, Netherlands, Norway, and Sweden formulated objections within 12 months: UN Multilateral Treaties (2009) (n 58) 312, 317, 323. Denmark submitted a communication after the expiration of the 12-month period: ibid 341, note 29.

${ }^{81}$ The government declared that it withdrew its reservation in respect of Arts 2(f), 9(1), 16(b), 16(d), 16(e), and 16(h). It also provided explanations on its remaining reservations. With respect to Article 5(a) of the Convention, the government of Malaysia declared that the provision was subject to the Syariah law on the division of inherited property. With respect to Art 7(b) of the Convention, the government of Malaysia declared that the application of said Art 7(b) would not affect appointment to certain public offices, such as the Mufti Syariah Court Judges, and the Imam which was in accordance with the provisions of the Islamic Shariah law. With respect to Art 9, para 2 of the Convention, the government of Malaysia declared that its reservation would be reviewed if the government amended the relevant law. With respect to Art 16.1 (a) and para 2, the government of Malaysia declared that under the Syariah law and the laws of Malaysia, the age limit for marriage for women was 16, and for men, was 18. See UN Multilateral Treaties (2009) (n 58) 341, note 35. 
Malaysian proposal led the depositary to ask other states whether they had any objections to the deposit of the Malaysian modified reservation or to the procedure envisaged by the depositary and to communicate any objections by 20 July 1998 . The depositary also specified that Malaysia's intended withdrawal would be effective only if no objection was received by this date. ${ }^{82}$ On 20 July 1998, France submitted the following reaction:

France considers that the reservation made by Malaysia, as expressed in the partial withdrawal and modifications made by Malaysia on 6 February 1998, is incompatible with the object and purpose of the Convention. France therefore objects to the [reservation]. This objection shall not otherwise affect the entry into force of the Convention between France and Malaysia. Consequently, the modification in question is not accepted, the Government of France having objected thereto. $^{83}$

As a consequence, confusion arose. For quite a long period of time, the depositary, Malaysia, and the ICEDAW Committee could not determine what was the situation with regard to Malaysia's reservations. ${ }^{84}$ The most adverse impact of this

\footnotetext{
82 ibid.

${ }^{83}$ ibid 342, note 35. The last sentence of the French statement no longer appears in the text of the official printed collection of multilateral treaties since the acceptance of Malaysia's partial withdrawal was decided. However, this last sentence appears in the version published on the website (see above $\mathrm{n}$ 58).

${ }^{84}$ The confusion can be illustrated by the following. In the CEDAW official document 'Declarations, reservations, objections and notifications of withdrawal of reservations relating to the CEDAW', its Annex I contains a comprehensive table of states parties that maintain their reservations. This table has, among others, two separate columns: one for reservations made and another for reservations withdrawn. This document in its 2000 edition contains no information on reservations withdrawn by Malaysia: see
} 
situation was the virtual retreat of Malaysia from the ICEDAW for about eight years. Malaysia resumed its active participation in the ICEDAW by submitting its initial report only in 2006, once consensus was reached and reflected in the UN documents that the withdrawal did take place.

The reaction of France should be compared to the reaction of the Netherlands to the very same proposed withdrawal by Malaysia. The Netherlands has a very consistent and regular record of objections to reservations based on Islam. It objected to almost all reservations invoking Islam, contrary to France, which did so only on a few occasions. Despite this regularity and respect for the 12-month period, when the Netherlands reacted to the proposed withdrawal of Malaysia, it submitted its reaction was on 21 July 1998, one day after the expiry of the time limit prescribed by the depositary. ${ }^{85}$ It is hardly possible that this is just a coincidence. Contrary to France, which has very limited experience in objecting to the reservations based on Islam and in conducting reservations dialogue, the government of the Netherlands is very skilful in this field.

Declarations, reservations, objections and notifications of withdrawal of reservations relating to the CEDAW, 20 July 2000, CEDAW/SP/2000/2. The corresponding space in the column 'withdrawn' is empty (see ibid 93). In the 2002 edition (Declarations, reservations, objections and notifications of withdrawal of reservations relating to the CEDAW, 26 July 2002, CEDAW/SP/2002/2), the situation is different. All the reservations intended by Malaysia for withdrawal are indicated as withdrawn (see ibid 77). In 2004 (CEDAW/SP/2004/2), surprisingly, only one reservation appears as withdrawn; namely, that to Art 2(f) (see ibid 28). In the document prepared in 2006 (CEDAW/SP/2006/2) all the reservations intended by Malaysia for withdrawal are again indicated as withdrawn (see ibid 51).

${ }^{85}$ UN Multilateral Treaties (2009) (n 58) 342, note 35. 
The reaction was comprised of a welcoming of the government's efforts and expressed the belief in Malaysia's respect of the reserved articles. ${ }^{86}$

While the reaction of France perfectly fits into the Vienna Convention regime and ensures that the Vienna Convention regime's consequences are produced, it does nothing but impede positive developments in the field of human rights. The reaction of the Netherlands is less straightforward. It is so careful that it does not even qualify the remaining reservations as incompatible with the object and purpose of the ICEDAW, although this idea is implied in its declaration that 'it assumes that Malaysia will ensure implementation of the rights enshrined in the above articles'. However, it engages in a dialogical conversation, provides space for the expression of views by the reserving state, and is respectful of the culture and efforts of this reserving state. The very similar open, respectful, and dialogical attitude of the majority of states participating in the reservations dialogue allowed for withdrawal of many problematic reservations and thus improvement of the situation of women. The important aspect of this process for our purposes is that this withdrawal, and thus the change in the attitude of reserving states, occurs from inside their own culture and religion. As a result, they accept the newly negotiated rights as reflecting also their own values and adhere to them sincerely. This fact is very important for the success of the future of human rights as international constitutional rights and as a part of the substantive international rule of law.

In a public discussion, if a participant makes an apparent effort to improve his or her compliance with the mainstream vision, responses similar to that made by France will only offend this participant. The reaction of the offended participant will be

\footnotetext{
${ }^{86}$ The text of the reaction is reproduced above ( $\left.\mathrm{n} 71\right)$ and in the accompanying text.
} 
stubbornness and refusal to continue negotiation, as happened with Malaysia. The Netherlands' reaction produces the contrary effect. Conducted in a public discussion, it even pushes the participant to continue its efforts by presenting it as a member of the human rights complying group.

Finally, some observations on certainty and predictability are required to clarify the nature of the international rule of law as shaped by the domestic experiences and values. First, since with regard to its human rights component, the international rule of law has only procedural significance, certainty and predictability are not as central to its successful operation as they would be for a substantive rule of law. However, since international human rights standards are important components of negotiation, which takes place between the domestic and the international rule of law, some level of certainty and predictability would be expected by all participants. In this regard, it should be recalled that domestic constitutional laws are also often formulated in very general terms. Interpretation and understanding of these terms evolves and changes over time without complaints about lack of certainty and predictability. All participants of this constant negotiative process taking place within the procedural international rule of law are able to know at all times how to adapt and model their behaviour so as not to infringe upon the existing rules: states submit reports and adopt legislation; committees examine these reports and give advice to states, but also issue decisions on complaints submitted by individuals.

\section{Conclusions}


This chapter started with the thesis that substantive human rights guarantees form an integral part of any rule of law worthy of its name. I also pointed out that the understanding of the place of human rights within the international rule of law is insufficient and unclear, especially if we consider the uneasy relationship between internationally formulated human rights standards and their domestic implementation. I proposed to shed more light on this issue by reflecting on the relationship between the international and the domestic rule of law within the context of the reservations dialogue.

The reservations dialogue, which is born out of uncertainties of the reservations regime as codified in the Vienna Convention, provided space and opportunities for interesting developments that reinforce the legitimacy of the international rule of law through negotiative practices involving the domestic rule of law of several states. Paradoxically, the very uncertainties which may be understood by some as contradictory to the rule of law in part facilitate the dialogue, which allows constant negotiation about the content of human rights obligations and more broadly, the substance of the international rule of law.

The examples of states' engagements in the reservation dialogue analysed above demonstrate the readiness of states to use the space provided by international law (in this case, the context of reservations to treaties) to engage in negotiations of the most complex but also the most important issues around the relationship between universal human rights and their domestic interpretation, the domestic and the international rule of law, universality, and diversity. The practices analysed also demonstrate an urgent 
need for broadening our view of the reservations dialogue beyond the confines of the Vienna Convention regime. In order to give full recognition to the negotiative processes taking place within the framework of the reservations dialogue, we need to recognise the value not only of legal effects of various reactions, but also their political, ethical, and interactive effects. We also need to realise the importance of the role played by actors not envisaged by the Vienna Convention regime, especially by treaty-monitoring bodies. I do not argue for the creation of new rules or regimes. It is more important to fully understand these dynamics, acknowledge their significance and various roles played, and be able to create conditions favourable to these valuable constructive engagements.

The above analysis of the reservations dialogue illuminates the following aspect of the interface between the domestic and the international rule of law. At this stage of the development of the international rule of law, it is difficult to speak about substance of the rule of law: the contours and content of human rights that are part of the international rule of law are quite obscure. However, we can clearly identify important negotiative or dialogical aspects of this relationship. While the domestic rule of law requires today an input from the international law (at least its human rights component) the international rule of law is also shaped by the constant contribution of the national legal orders. At this stage of development of the international rule of law it functions rather as an arena, a relatively neutral and open space where substantive values can be negotiated and renegotiated. This ability of the international law to create and sustain this space is the most valuable contribution of the international rule of law which also sustains its legitimacy. It should also be observed that without this input from the domestic rule of law experience, no international rule of law, even as a procedural 
mechanism, would arise. Theoretically, the conundrum which emerges is the fact that the arena where substantive rule of law values are negotiated and then absorbed by various domestic versions of the rule of law does not seem to have itself any substantive values except those linked to the regulation of interactions taking place within it. Paradoxically, while today's understanding of the domestic rule of law seems to suggest that it must comply with international human rights standards, there are no such fixed standards. These standards emerge only though a constant and on-going negotiation within the space provided by the international rule of law. The circular negotiative process which involves mutual influence and interaction between various domestic rules of law and the international rule of law is the only substance we can identify today within the international rule of law.

Perhaps the time will come when we will be able to speak of the international rule of law in a substantive sense; but we should be aware of the aspirational nature of any such substantive definition. Today, the ability of the international rule of law to provide and keep this open negotiative space is more important than the substantive values of the international rule of law themselves. And if we agree that international law should not mutate into a super-state, then this international rule of law will always remain something qualitatively different from the domestic rule of law and its emphasis on a series of defined standards. 